\title{
Penerapan Algoritma Levenshtein Pada Aplikasi Kamus Istilah Militer Tni Berbasis Android
}

\author{
Diky Wahyud1 ${ }^{1}$, Rika Rosnelly ${ }^{2 *}$, Rofiqoh Dewi ${ }^{3}$ \\ 1,2*3Program studi Informatika Universitas Potensi Utama \\ E-mail: dikyywahyudii@gmail.com ${ }^{1}$, rikarosnelly@gmail.com²*,dezie.wie@gmail.com³
}

\begin{abstract}
Abstrak
Daftar istilah militer TNI sangat banyak jumlahnya, hal tersebut dapat menjadi masalah bagi prajurit TNI ketika mendengar istilah dari atasan tapi tidak mengerti maksud dari istilah tersebut. Masalah lainnya dapat juga ditemukan saat calon TNI yang sedang melaksanakan berbagai tes dan menemukan salah satu kata istilah dan tidak memahami maknanya. Untuk itu dibutuhkan sebuah media yang dapat digunakan dalam mengatasi masalah tersebut. Penelitian ini membangun sebuah aplikasi kamus yang berisikan istilah-istilah tentang militer TNI. Aplikasi kamus yang akan dibangun tentu saja harus dapat digunakan secara mobile sehingga mudah dalam proses penggunaannya. Aplikasi kamus yang dibangun juga harus memiliki kolom pencarian yang dapat digunakan untuk mencari kata istilah tertentu sehingga cepat untuk menemukan arti dari sebuah kata istilah militer TNI. Untuk meningkatkan optimasi pencarian kata istilah dan menampilkan hasil pencarian dengan cepat, maka pada pembangunan aplikasi ini akan diterapkan algoritma levenshtein, digunakan untuk mesin pencari istilah militer TNI berbasis android. Algoritma ini menghitung jumlah operasi string paling sedikit yang diperlukan untuk mentransformasikan suatu string menjadi string yang lain. Tujuan dari penelitian ini yaitu menghasilkan sebuah aplikasi kamus istilah militer TNI dengan menerapkan algoritma levenshtein untuk mempermudah proses pencarian istilah militer TNI walaupun terdapat kesalahan kata yang di input pada kolom pencarian karena aplikasi akan tetap menampilkan saran istilah militer TNI yang mungkin dicari.
\end{abstract}

Kata kunci : Kamus, Istilah TNI, Levenshtein, android

\begin{abstract}
The list of TNI military terms is very large, it can be a problem for TNI soldiers when they hear the term from their superiors but do not understand the meaning of the term. Other problems can also be found when TNI candidates who are carrying out various tests and find one of the terms and do not understand its meaning. For that we need a media that can be used to overcome these problems. This study builds a dictionary application that contains terms about the TNI military. The dictionary application that will be built, of course, must be able to be used on a mobile basis so that it is easy to use. The dictionary application that is built must also have a search column that can be used to search for certain terms so that it is fast to find the meaning of a TNI military term. To improve search optimization of terms and display search results quickly, in the development of this application, the Levenshtein algorithm will be applied, used for the TNI military term search engine based on Android. This algorithm calculates the least number of string operations required to transform one string into another. The purpose of this research is to produce a military term dictionary application by applying the Levenshtein algorithm to simplify the process of searching for TNI military terms even though there are word errors entered in the search field because the application will still display suggestions for TNI military terms that may be searched.
\end{abstract}

Keywords: Dictionary, Glossary of TNI, Levenshtein, android 


\section{PENDAHULUAN}

Istilah militer Tentara Nasional Indonesia merupakan istilah yang selalu digunakan oleh militer, dalam hal ini Tentara Nasional Indonesia. Bagi masyarakat awam, istilah-istilah militer sering membingungkan, daftar istilah militer TNI sangat banyak jumlahnya, hal tersebut dapat menjadi masalah bagi prajurit TNI ketika mendengar istilah dari atasan tapi tidak mengerti maksud dari istilah tersebut. Masalah lainnya dapat juga ditemukan saat calon TNI yang sedang melaksanakan berbagai tes dan menemukan salah satu kata istilah dan tidak memahami maknanya. Untuk itu dibutuhkan sebuah media yang dapat digunakan dalam mengatasi masalah tersebut. Untuk mengatasi masalah tersebut di atas, dapat dilakukan dengan cara membangun sebuah aplikasi kamus yang berisikan istilah-istilah tentang militer TNI. Aplikasi kamus yang akan dibangun tentu saja harus dapat digunakan secara mobile sehingga mudah dalam proses penggunaannya. Aplikasi kamus yang dibangun juga harus memiliki kolom pencarian yang dapat digunakan untuk mencari kata istilah tertentu sehingga cepat untuk menemukan arti dari sebuah kata istilah militer TNI.

Penelitian [1] merancang aplikasi sinonim dan antonim yang dapat memudahkan seseorang untuk mempelajari lebih banyak kosakata, persamaan kata dan lawan kata dalam aplikasi tersebut. Penelitian ini membuat aplikasi kamus sinonim dan antonim berbahasa Indonesia berbasis android agar dapat memudahkan pengguna nantinya. Aplikasi kamus sinonim dan antonim ini menggunakan metode pencarian biner (binary search).

Penelitian [2] dengan perangkat lunak terjemah ini, semua orang dapat memperlajari berbagai bahasa khususnya bahasa minang tanpa harus datang ke daerah masyarakat minang. Aplikasi ini menerapkan metode levenshtein, merupakan algoritma yang dipakai dengan luas untuk bermacam-macam bidang, contohnya mesin untuk mencari pada browser, untuk mengecek ejaan atau biasa disebut spellchecking, untuk mengenal pembicaraan atau biasa disebut speech recognition, analisis DNA, dll.

Penelitian [3] saat ini android sangat diminati oleh masyarakat, dari semua kalangan atas sampai kalangan bawah. Disamping bahasa Indonesia, juga membutuhkan bahasa lainnya, maka kita membutuhkan pengetahuan serta pemahaman dalam istilah atau arti kata Biologi. Dengan adanya kamus elektronik ini sangat membantu terutama bagi pelajar, mahasiswa serta masyarakat dari semua kalangan generasi muda.

Penelitian [4] Optimasi Pencarian Kata pada Aplikasi Penerjemah Bahasa MandarinIndonesia Berbasis Android dengan Algoritma Levenshtein Distance".Penelitian tersebut bertujuan untuk membangun sebuah aplikasi penerjemah bahasa Mandarin Indonesia untuk digunakan pada smartphone android dengan penerapan algoritma Levenshtein untuk meningkatkan hasil pencarian kata.

Menurut penelitian [5] Optimasi Pencarian Kata Pada Kamus Aneka Bahasa Menggunakan Algoritma Levenshtein Distance". Penelitian tersebut telah menghasilkan aplikasi berbasis desktop untuk terjemahan dengan optimasi pencarian menggunakan algoritma Levenshtein. Tujuan penggunaan algoritma levenshtein pada aplikasi tersebut adalah untuk memberikan kumpulan kata yang memiliki kemiripan dari kata yang dicari pada aplikasi kamus tersebut.

Menurut Penelitian [6] dalam Implementasi Algoritma Levenshtein Pada Sistem Pencarian Judul Skripsi/Tugas Akhir". Penelitian tersebut dilakukan untuk menghasilkan sebuah aplikasi yang dapat digunakan untuk mencari judul skripsi maupun tugas akhir. Pada aplikasi tersebut diterapkan algoritma levenshtein yang bertujuan untuk mengoptimasi hasil pencarian kata sehingga aplikasi akan menampilkan kumpulan kata yang memiliki kemiripan dengan kata yang dicari.

Menurut Penelitian [7] melakukan implementasi fitur autocomplete dan Algoritma Levenshtein Distance untuk Meningkatkan Efektivitas Pencarian Kata di Kamus Besar Bahasa Indonesia (KBBI). Penelitian ini menghasilkan sebuah aplikasi yang memberikan sugesti dari huruf yang di input berdasarkan kumpulan kata yang terdapat pada Kamus Besar Bahasa Indonesia (KBBI). 
Menurut Penelitian [8] menghasilkan sebuah aplikasi penerjemah dari bahasa Bima ke bahasa Indonesia dengan penerapan Algoritma Levenshtein yang bertujuan untuk melakukan pengecekan kata pencarian apakah sudah sesuai dengan kumpulan kata pada aplikasi kamus bahasa Bima-bahasa Indonesia yang dibangun.

\section{METODE PENELITIAN}

Adapun Metode Yang Digunakan Pada Penelitian ini adalah Diagram Fishbone dapat dilihat pada Gambar 1.

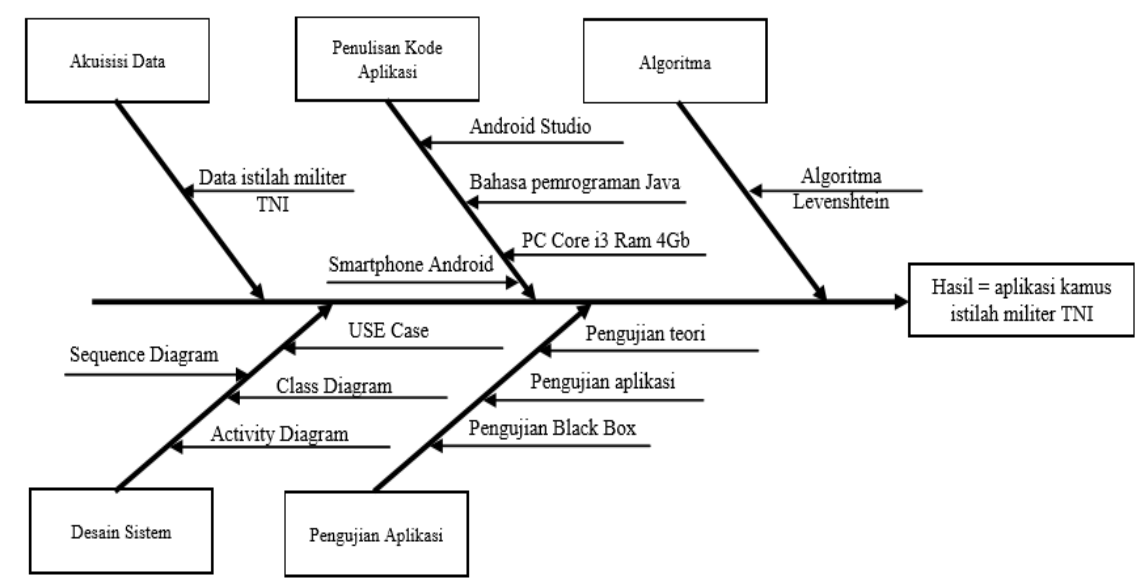

Gambar 1. Metode Diagram Fishbone Prosedur Perancangan Penerapan Algoritma Levenshtein Dalam Pembuatan Aplikasi Kamus Istilah Militer TNI Berbasis Android

Penjelasan Gambar 1 Prosedur Perancangan Penerapan Algoritma Levenshtein Dalam Pembuatan Aplikasi Kamus Istilah Militer TNI Berbasis Android pada Metode Diagram Fishbone :

1. Akuisisi Data

Pada tahap akuisisi data pada diagram fishbone adalah mengumpulkan data istilah militer TNI yang akan digunakan pada aplikasi kamus yang akan dibangun pada penelitian ini.

2. Desain Sistem

Pada tahap ini dirancang sebuah desain dari penerapan algoritma levenshtein dalam pembuatan aplikasi kamus istilah militer TNI berbasis android. Bagaimana desain yang akan digunakan pada antarmuka perangkat berbasis android Setelah dilakukan perancangan desain aplikasi selanjutnya melakukan implementasi terhadap desain antarmuka dari aplikasi berbasis android yang telah dirancang kedalam bahasa pemrograman JAVA.

3. Algoritma

Pada tahap ini akan digunakan algoritma Levenshtein, yaitu algoritma yang digunakan untuk mencari jumlah operasi string yang paling sedikit untuk mentransformasikan suatu string menjadi string yang lain. Algoritma ini digunakan dalam pencarian string dengan pendekatan perkiraan. Proses algoritma Levenshtein selanjutnya akan dijabarkan untuk selanjutnya dituangkan ke dalam bahasa pemrograman yang akan digunakan dalam membangun aplikasi kamus istilah militer TNI ini, yaitu bahasa pemrograman Java. Algoritma yang digunakan adalah Levenshtein yang bertujuan untuk digunakan dalam proses optimasi hasil pencarian kata istilah militer TNI.

4. Penulisan Kode Aplikasi

Pada proses ini penerapan algoritma Levenshtein dalam pembuatan aplikasi kamus istilah militer TNI berbasis android dituangkan kedalam bahasa pemrograman Java dan mulai dibangun menggunakan perangkat lunak Android Studio untuk menghasilkan sebuah aplikasi sesuai dengan perancangan. Seluruh fungsi dan antarmuka yang terdapat pada perancangan akan disesuaikan dengan aplikasi yang akan dihasilkan. 
5. Pengujian Aplikasi

Pada tahap ini dilakukan pengujian aplikasi kamus istilah militer TNI pada smartphone android secara menyeluruh, meliputi pengujian fungsional dan pengujian ketahanan aplikasi. Pengujian fungsional dilakukan untuk mengetahui bahwa aplikasi kamus istilah militer TNI telah berjalan dengan sesuai dengan perancangan. Pengujian ketahanan merupakan kemampuan aplikasi untuk berjalan dengan baik pada spesifikasi minimum komputer. Proses pengujian aplikasi juga dilakukan menggunakan metode Black Box untuk mengetahui fungsional dari setiap tampilan dan menu yang terdapat pada aplikasi agar sesuai dengan perancangan.

6. Hasil

Hasil yang diharapkan pada penelitian ini adalah sebuah aplikasi kamus yang berisikan istilah militer TNI untuk digunakan pada smartphone android. Pada tahap ini juga akan diambil kesimpulan dari penerapan algoritma levenshtein dalam pembuatan aplikasi kamus istilah militer TNI berbasis android yang telah dihasilkan, seperti apa saja kelebihan dan kekurangan dari penerapan algoritma levenshtein dalam pembuatan aplikasi kamus istilah militer TNI berbasis android. Sehingga didapatkan kesimpulan untuk menambahkan fungsi-fungsi tertentu sesuai dengan kebutuhan kedalam aplikasi.

\section{HASIL DAN PEMBAHASAN}

\subsection{Analisis Masalah}

Pada penelitian ini akan dibangun sebuah aplikasi kamus yang berisikan kata-kata istilah militer TNI. Kata-kata tersebut bukanlah kata-kata yang umum digunakan dalam kegiatan sehari-hari sehingga terkadang kesalahan dalam penulisan kata istilah militer TNI sering kali terjadi dan menambah waktu proses pencarian suatu kata istilah. Proses pencarian dalam suatu aplikasi kamus sangatlah penting, namun terkadang proses pencarian suatu kata dalam sebuah aplikasi kamus dapat menjadi lambat karena terjadi kesalahan dalam input kata yang akan dicari. Untuk mempercepat dan mempermudah suatu proses pencarian kata dalam sebuah aplikasi kamus, dibutuhkan suatu algoritma yang dapat memaksimalkan proses pencarian tersebut. Pada penelitian ini untuk mengatasi kesalahan input kata dalam proses pencarian pada aplikasi kamus akan digunakan algoritma Levenshtein. Penggunaan algoritma Levenshtein pada penelitian ini diharapkan dapat mengatasi kesalahan input kata istilah yang dilakukan pada proses pencarian dalam aplikasi kamus yang akan dihasilkan.

\subsection{Desain Sistem}

\section{a. Usecase Diagram}

Dilihat dari use case diagram aplikasi yang akan dibangun memiliki dua buah menu pada halaman utama saat aplikasi dijalankan. Menu tersebut adalah menu istilah TNI yang memiliki case lain yaitu case pencarian istilah militer TNI tertentu dan juga case untuk menampilkan istilah militer TNI yang dipilih beserta artinya. Menu lainnya adalah menu tentang aplikasi yang digunakan untuk menampilkan informasi tentang aplikasi yang akan dibangun pada penelitian ini, Adapun Usecase diagram aplikasi ditunjukkan pada Gambar 2.

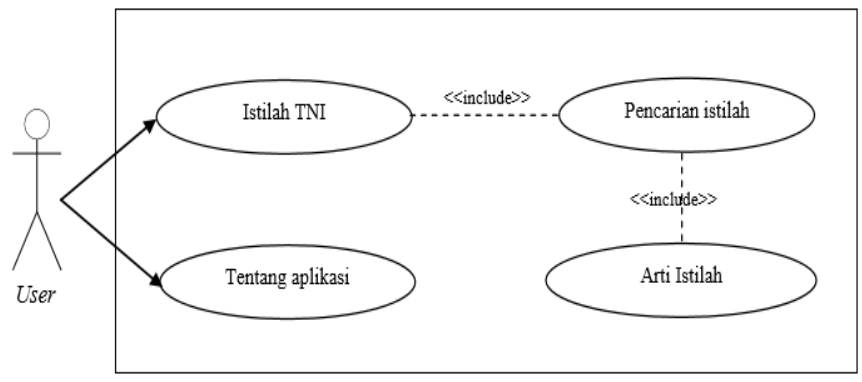

Gambar 2. Usecase Diagram 
Pada usecase diagram tersebut terlihat user dapat mengakses 2 menu utama sebagai tampilan awal, yaitu menu istilah TNI, dimana pada saat menu ini digunakan dengan mengetikkan istilah yang akan kita cari, maka sistem akan melakukan pencarian istilah tersebut dan menampilkan arti dari istilah yang kita cari. Dimana pada proses ini algoritma levenshtein akan mengubah kata ketika terjadi kesalahan dalam pengejaan pada pengetikan kata menjadi sebuah kata kunci yang utuh sesuai dengan kata yang terdapat dalam database dimana jarak pengubah pada pencarian kata kunci tersebut dibatasi dengan jarak 0 (nol) sampai 3 (tiga). Menu yang kedua yaitu tentang aplikasi yang berisi tentang informasi penggunaan aplikasi.

b. Activity Diagram Istilah TNI

Activity diagram istilah TNI merupakan activity diagram saat memilih menu istilah TNI pada aplikasi dimana user memilih menu istilah TNI lalu sistem akan menampilkan halam istilah TNI dan user menginputkan kata yang akan dicari pada kolom pencarian dan sistem akan menampilkan hasil pencarian istilah tersebut dan user akan memilih kata istilah TNI yang dimaksud selanjutnya sistem akan menampilkan arti dari kata istilah TNI yang dipilih. Activity diagram istilah TNI ditunjukkan pada Gambar 3.

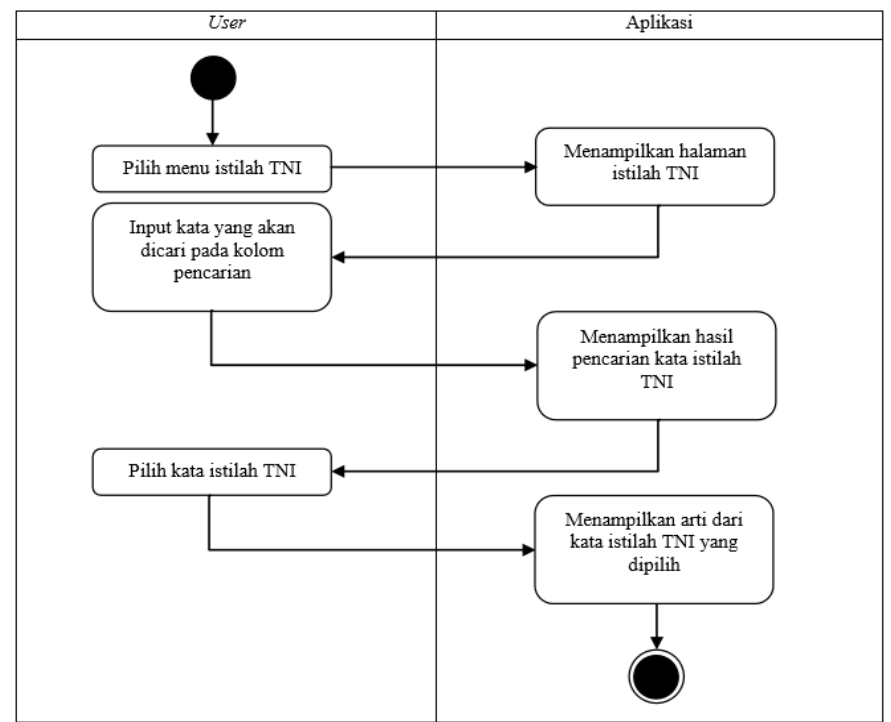

Gambar 3. Activity Diagram Istilah TNI

c. Activity Diagram Tentang Aplikasi

Activity diagram tentang aplikasi merupakan activity diagram saat memilih menu tentang aplikasi dimana user melakukan pilih menu tentang aplikasi lalu sistem akan menampilkan halaman tentang aplikasi. Activity diagram tentang aplikasi ditunjukkan pada Gambar 4.

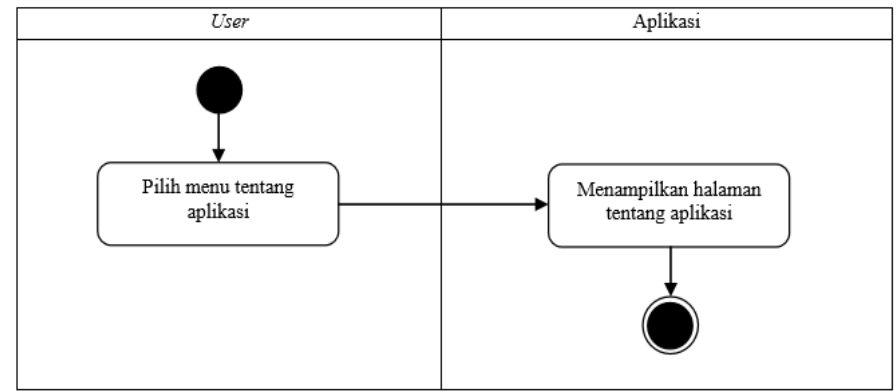

Gambar 4. Activity Diagram Tentang Aplikasi 
d. Sequence Diagram Istilah TNI

Sequence diagram istilah TNI menggambarkan interaksi yang terjadi dalam proses memilih menu istilah TNI. Menu ini digunakan untuk menampilkan halaman yang berisikan istilah-istilah TNI. Pada halaman ini juga terdapat sebuah kolom pencarian untuk menemukan kata istilah TNI tertentu yang akan dicari. Sequence diagram istilah TNI ditunjukkan pada Gambar.5.

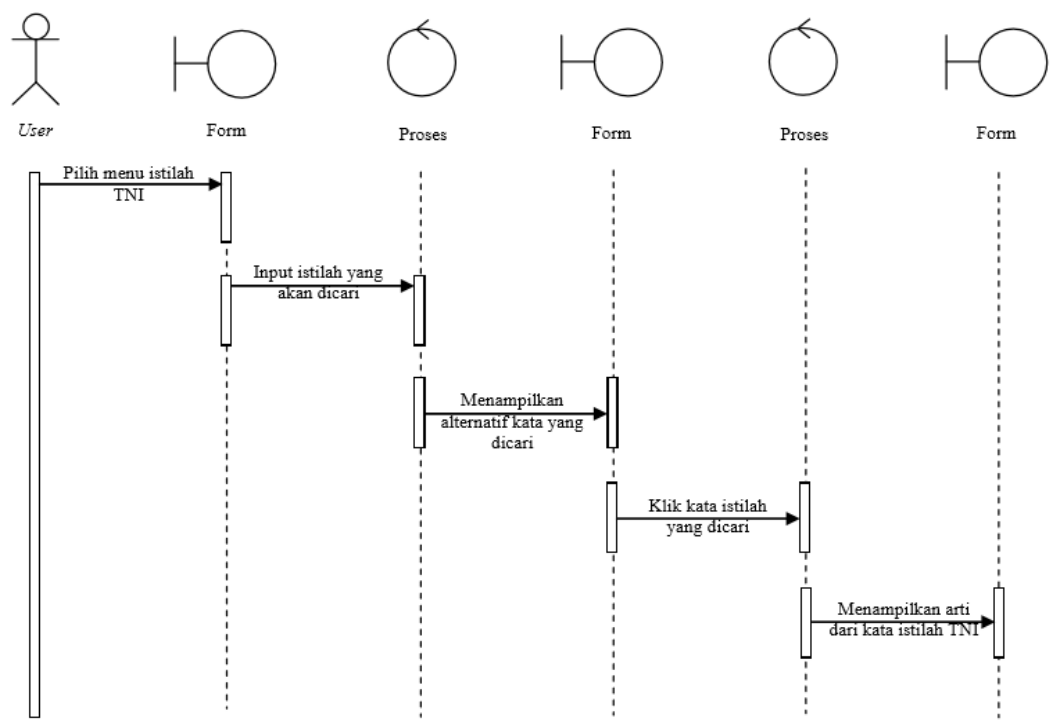

Gambar.5. Sequence Diagram Istilah TNI

e. Sequence Diagram Tentang Aplikasi

Sequence diagram tentang aplikasi menggambarkan proses yang terjadi pada saat memilih menu tentang aplikasi. Halaman tentang aplikasi akan menampilkan informasi tentang cara penggunaan aplikasi dan juga informasi penelitian yang dibuat. Sequence diagram tentang aplikasi ditunjukkan pada Gambar.6.

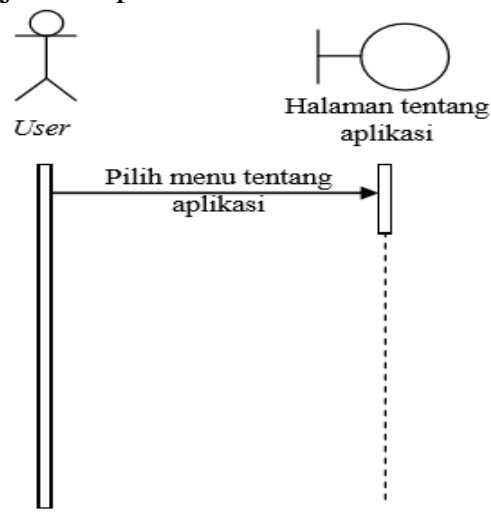

Gambar 6. Sequence Tentang Aplikasi

f. Class Diagram

Rancangan kelas-kelas yang akan digunakan pada sistem dapat dilihat pada Gambar 7. 


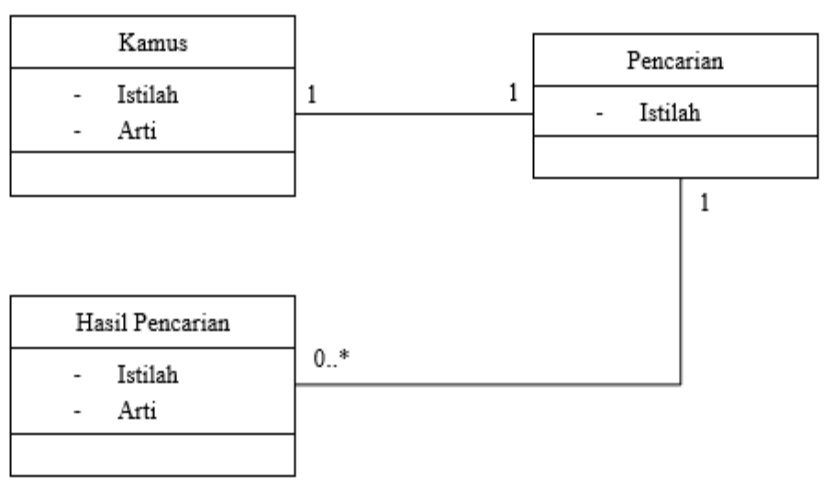

Gambar 7 . Class diagram

\subsection{Tampilan Hasil}

Berikut Ini ini akan dijelaskan tampilan hasil dari aplikasi yang telah dibuat, yang digunakan untuk memperjelas tentang tampilan-tampilan yang ada pada aplikasi kamus istilah militer TNI saat dijalankan pada smartphone android.

1. Tampilan Halaman Utama

Pada tampilan halaman utama terdapat dua tombol menu, yaitu tombol menu istilah TNI untuk menampilkan halaman istilah TNI dan tombol menu tentang aplikasi untuk menampilkan halaman tentang aplikasi. Gambar tampilan halaman utama ditunjukkan pada Gambar 8.

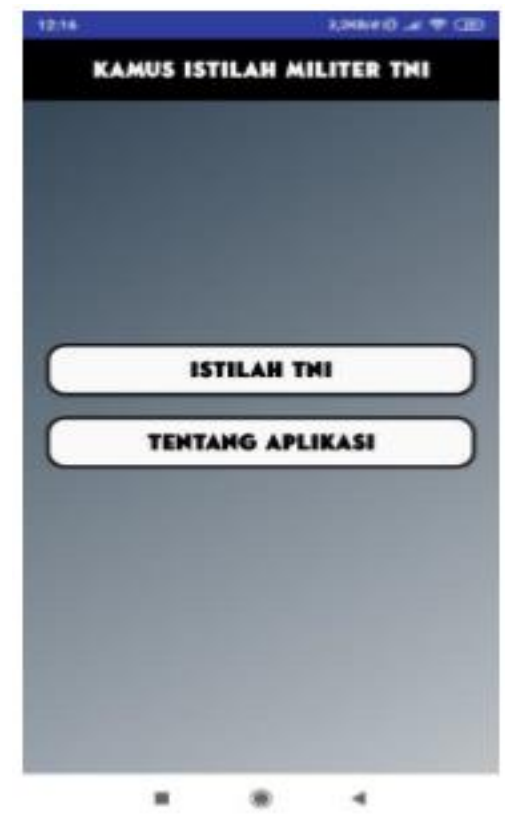

Gambar 8 Tampilan Halaman Utama

2. Tampilan Halaman Istilah TNI

Pada halaman istilah TNI ditampilkan daftar istilah-istilah yang dipakai dalam militer TNI. Gambar tampilan halaman istilah TNI ditunjukkan pada Gambar 9. 


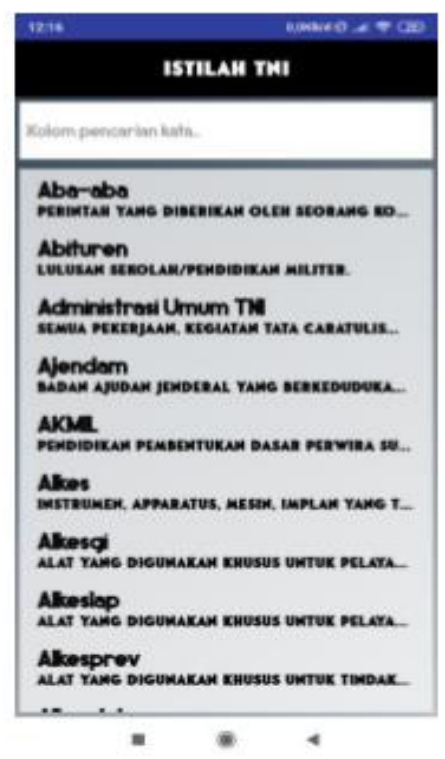

3. Tampilan Proses Pencarian

Gambar 9. Tampilan Halaman Istilah TNI

Tampilan pencarian merupakan tampilan proses mencari suatu istilah TNI menggunakan aplikasi. Setelah menginputkan huruf, aplikasi akan menampilkan istilah TNI yang sesuai dengan huruf pada kolom pencarian. Dimana pada proses ini algoritma levenshtein akan mengubah kata ketika terjadi kesalahan dalam pengejaan pada pengetikan kata menjadi sebuah kata kunci yang utuh sesuai dengan kata yang terdapat dalam database dimana jarak pengubah pada pencarian kata kunci tersebut dibatasi dengan jarak 0 (nol) sampai 3 (tiga). Gambar tampilan proses pencarian ditunjukkan pada Gambar 10.

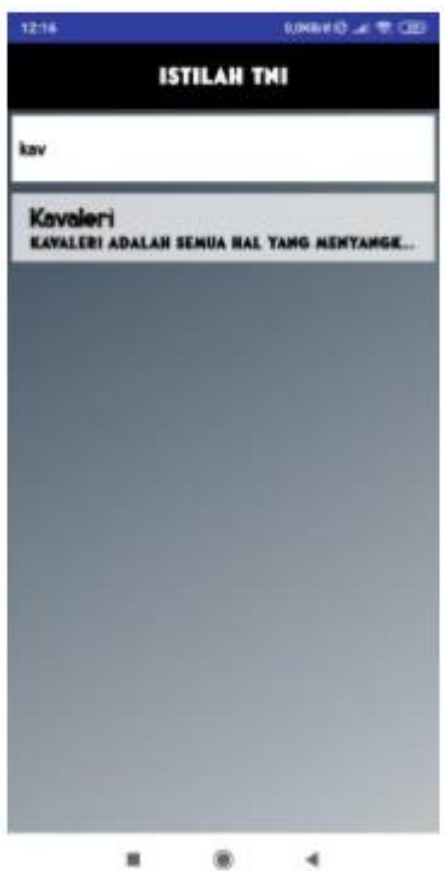

Gambar 10. Tampilan Proses Pencarian

4. Tampilan Halaman Arti Istilah

Pada halaman arti istilah, aplikasi akan menampilkan arti dari istilah TNI yang dipilih pada halaman istilah TNI. Gambar tampilan halaman arti istilah ditunjukkan pada Gambar 11. 
ISSN : $2356-\mathbf{5 1 9 5}$

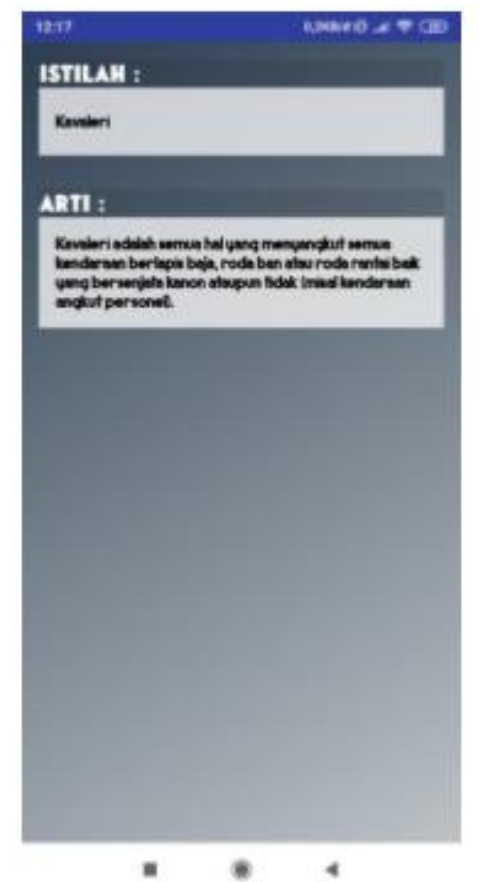

Gambar 11. Tampilan Halaman Arti Istilah

5. Tampilan Halaman Tentang Aplikasi

Pada halaman tentang aplikasi menampilkan informasi dari penelitian dan juga cara penggunaan aplikasi yang telah dihasilkan. Gambar tampilan halaman tentang aplikasi ditunjukkan pada Gambar 12.

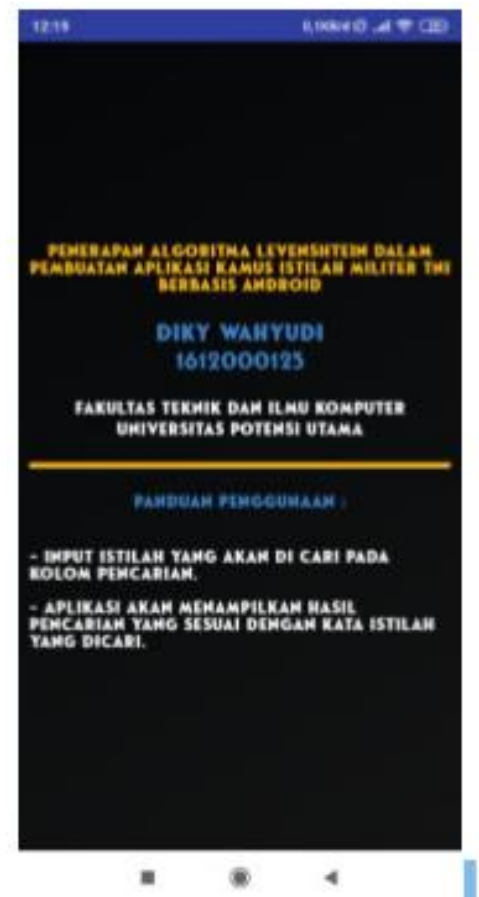

Gambar 12. Tampilan Halaman Tentang Aplikasi 


\subsection{Uji Coba Program}

Penulis melakukan pengujian black box terhadap aplikasi untuk mengetahui hasil dari perancangan antar muka aplikasi saat dijalankan pada smartphone android. Hasil pengujian dapat dilihat pada Tabel 1 .

Tabel 1. Hasil Uji Coba

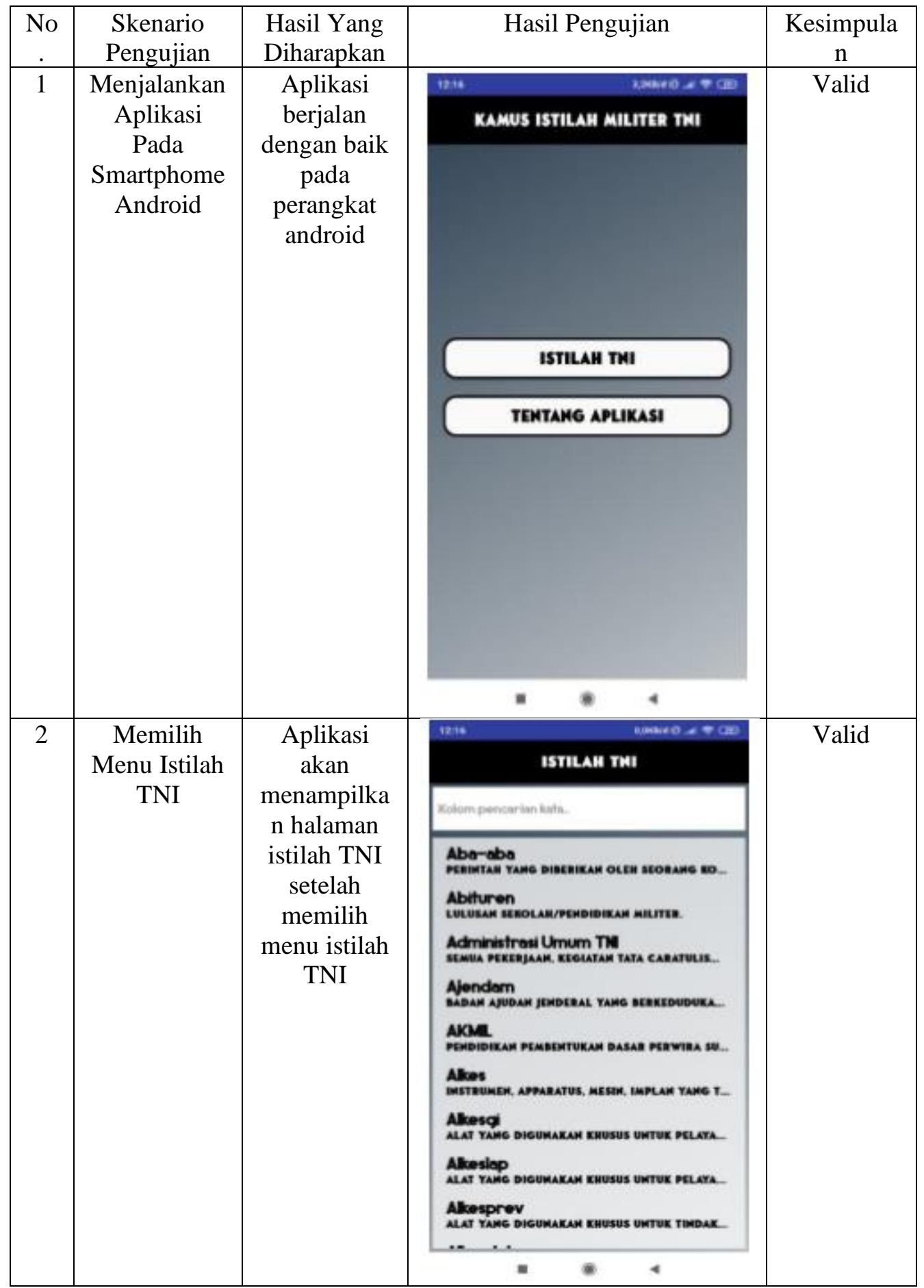




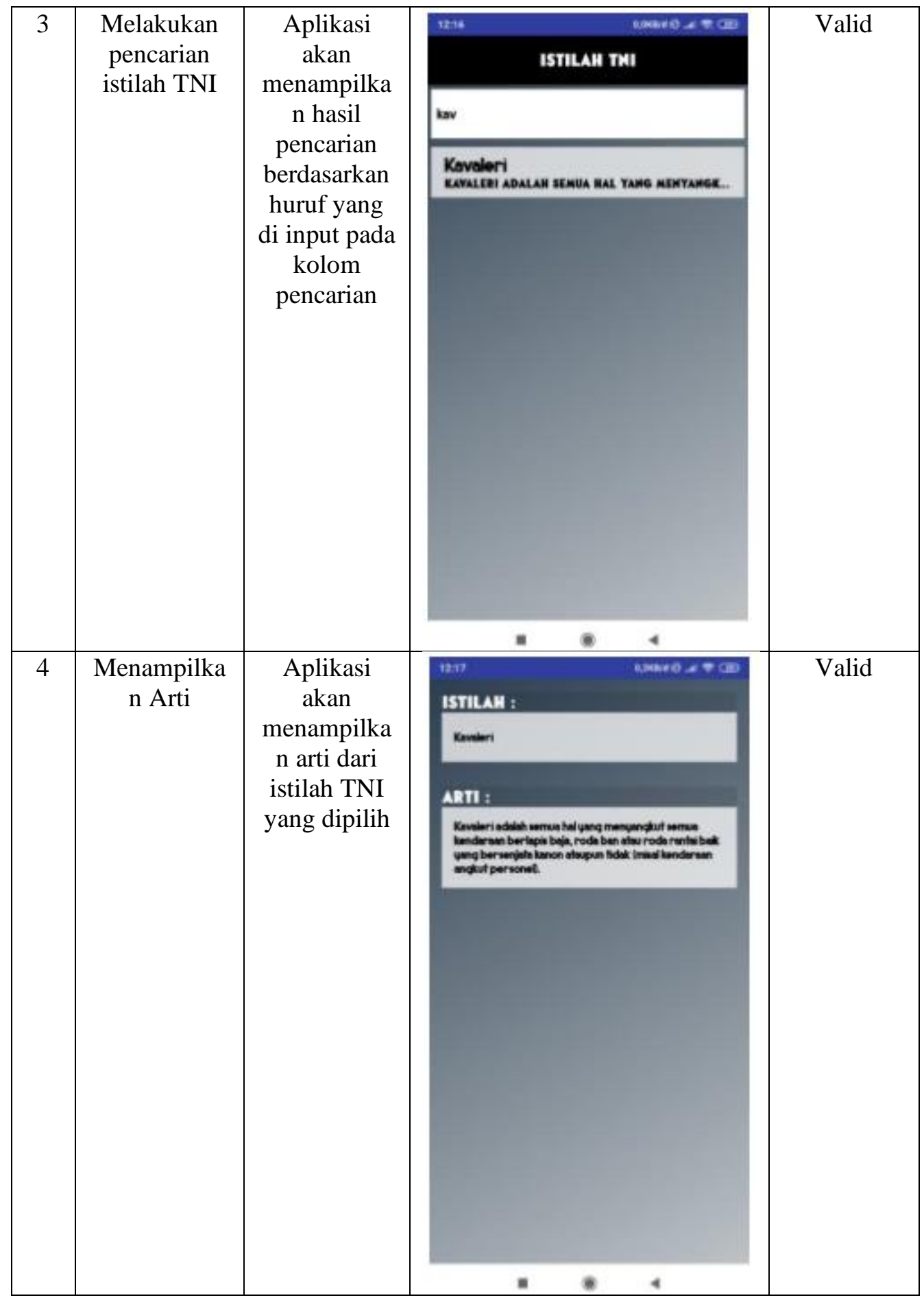

\section{KESIMPULAN}

Berdasarkan hasil pambahasan dan uji coba yang telah dilakukan, dapat disimpulkan :

1. Pada penelitian ini telah dihasilkan sebuah aplikasi kamus yang berisikan istilah militer TNI yang dapat digunakan secara umum untuk membantu mengetahui dan mengenal istilah-istilah dalam militer TNI.

2. Telah diterapkan algoritma Levenshtein pada aplikasi kamus yang dihasilkan untuk mempermudah proses pencarian istilah militer TNI, sehingga jika terdapat kesalahan kata yang 
di input pada kolom pencarian, aplikasi akan tetap menampilkan saran istilah militer TNI yang mungkin dicari.

\section{SARAN}

Untuk menyempurnakan aplikasi ini maka diberikan saran :

1. Diharapkan untuk menambahkan fitur agar pengguna dapat menambahkan istilah militer TNI yang baru secara mandiri pada aplikasi.

2. Diharapkan untuk penambahan fitur pencarian melalui internet jika istilah TNI yang dicari tidak ditemukan pada database aplikasi.

\section{DAFTAR PUSTAKA}

[1] Fernanda, F., \& Rosnelly, R. (2020). Perancangan Aplikasi Kamus Sinonim Dan Antonim Berbahasa Indonesia Berbasis Android. Jurnal Mahasiswa Fakultas Teknik dan Ilmu Komputer, 1(1), 883-898.

[2] Sari, N. (2020). Perancangan Aplikasi kamus Bahasa Minang Indonesia Dan Indonesia Minang Menggunakan Algoritma Levenshtein. Jurnal Mahasiswa Fakultas Teknik dan Ilmu Komputer, 1(1), 1113-1124.

[3] WANITRI, S. (2019). PERANCANGAN APLIKASI KAMUS BIOLOGI DENGAN METODE PENCARIAN BINER.

[4] Peggy, P., \& Hansun, S. (2015). Optimasi pencarian kata pada aplikasi penerjemah bahasa mandarin-indonesia berbasis android dengan algoritma levenshtein distance. Ultima Computing: Jurnal Sistem Komputer, 7(1), 19-23.

[5] Arnawa, I. B. K. S. (2018). Optimasi Pencarian Kata Pada Kamus Aneka Bahasa Menggunakan Algoritma Levenshtein Distance. Jurnal Sistem dan Informatika (JSI), 12(2), 149-157.

[6] Arnawa, I. B. K. S. (2017). Implementasi Algoritma Levenshtein Pada Sistem Pencarian Judul Skripsi/Tugas Akhir. Jurnal Sistem dan Informatika (JSI), 11(2), 46-53.

[7] Ngafidin, K. N. M. (2016). Implementasi fitur autocomplete dan algoritma levenshtein distance untuk meningkatkan efektivitas pencarian kata di kamus besar bahasa Indonesia (KBBI) (Doctoral dissertation, Universitas Negeri Semarang).

[8] Sari, Y. P., Pradnyana, G. A., \& Wirawan, I. M. A. (2019). Pengembangan Aplikasi Kamus Bahasa Bima-Bahasa Indonesia Menggunakan Algoritma Levenshtein Distance Sebagai Spell Checker Berbasis Android. Karmapati (Kumpulan Artikel Mahasiswa Pendidikan Teknik Informatika), 8(2), 86-95. 